\title{
Characterisation of quinoa (Chenopodium quinoa Willd.) accessions for the saponin content in Mediterranean environment
}

\author{
Giuditta De Santis, ${ }^{1}$ Carmen Maddaluno, ${ }^{1}$ Tiziana D'Ambrosio,, ${ }^{2}$ Agata Rascio, ${ }^{1}$ \\ Michele Rinaldi, ${ }^{1}$ Jacopo Troisi ${ }^{3}$ \\ ${ }^{1}$ Research Centre for the Cereal, Council for Agricultural Research and Economics, Foggia; \\ ${ }^{2}$ Department of Agriculture, Food and Environment, University of Foggia; \\ ${ }^{3}$ Laboratorio Chimico-Merceologico, Camera di Commercio, Napoli, Italy
}

\begin{abstract}
Seeds of the Andean seed crop quinoa (Chenopodium quinoa Willd.) usually contain saponins in the seed coat. Saponins give a bitter taste sensation and are a serious antinutritional factor, therefore selection of sweet genotypes with a very low saponin content in the seeds is a main breeding goal. The objective of this work was to identify, within germplasm lines of quinoa, previously selected for production and quality traits, superior genotypes low in saponins. For this purpose the total saponin content was determined in seeds of eight lines of quinoa and one variety (cv. Regalona Baer) as a control, previously evaluated over a 2 -year period in a Southern Italy environment. Significant variation for the saponin content was observed among the evaluated genotypes. The total saponin content ranged from 0.10 to $1.80 \%$, with the Q12 genotype showing the lowest value, suggesting the possibility of selecting genotypes sweet to be used in subsequent genetic improvement programs. Based on these results, in fact, it was possible to identify, among the accessions previously selected, particularly suitable for growing in Mediterranean area, some genotypes with high yields of seed ( 2.5 tha $^{-1}$, on average), high protein ( $17 \%$, on average) and fibres (13\%, on average) and low content in saponins ( $0.57 \%$, on average).
\end{abstract}

Correspondence: Giuditta De Santis, Consiglio per la ricerca in agricoltura e l'analisi dell'economia agraria (CREA) - Centro di Ricerca per la Cerealicoltura, S.S. $673, \mathrm{Km} 25,200$, Foggia, Italy.

E-mail: giuditta.desantis@crea.gov.it

Key words: Quinoa; grain saponin content; genotypes; seed yield.

Conference presentation: SIA XLIV Congress, Bologna, 2015.

Received for publication: 25 February 2016.

Revision received: 23 May 2016.

Accepted for publication: 28 May 2016.

CC Copyright G. De Santis et al., 2016

Licensee PAGEPress, Italy

Italian Journal of Agronomy 2016; 11:774

doi:10.4081/ija.2016.774

This article is distributed under the terms of the Creative Commons Attribution Noncommercial License (by-nc 4.0) which permits any noncommercial use, distribution, and reproduction in any medium, provided the original author(s) and source are credited.

\section{Introduction}

Chenopodium quinoa Willd. (Amaranthaceae), a staple food of the Andean communities, commonly known as quinoa, is an emerging grain crop that is grown for its edible seeds.

Quinoa is of considerable scientific and commercial interest in many regions of the world because of the nutritional composition of their seeds with a high-quality proteins content (14-20\%), fats and antioxidants, which are at least 5-fold higher than those of cereal flours (Koziol, 1992; Jacobsen et al., 2003; Bhargava et al., 2006).

Quinoa is also a good source of dietary fibre and contains relatively high quantities of vitamins and minerals, iron and calcium (Risi and Galwey, 1984). Furthermore, because of the absence of gluten proteins, quinoa can be used to produce gluten-free cereal-based products, and can thus be eaten by people who have celiac disease, as well as by those who are allergic to wheat (Gambus et al., 2002; Chillo et al., 2009). The genetic variability of quinoa is huge, with cultivars of quinoa being adapted to growth from sea level to an altitude of over 4000 meters and from cold, highland climates to subtropical conditions. This make it possible to select, adapt, and breed cultivars for a wide range of environmental conditions such as arid or humid areas, cold or hot environments, acidic or alkaline soils (Jacobsen, 2003). Therefore, several countries in all over the world started in the last years to promote researches for the development of quinoa cultivation. The main obstacle for introducing quinoa into Europe is the length of its growing season and its sensitivity to the photoperiod (Bertero, 2001; Casini, 2002). In these terms, the best results have been obtained with material that originated from Chile (Jacobsen, 1997), which is adapted to a photoperiod that is similar to that of temperate areas.

Quinoa is a complete and versatile food, that can be prepared in several ways: as whole grain or flour, for sweet or savory foods that are hot or cold, or even as a drink, all of which offer wide potential for future technological applications (pasta, bread, beer, breakfast cereals, biscuits, protein concentrates) (Tosi et al., 1996; Gambus et al., 2002). However, one factor that limits its widespread use is the bitter taste, caused by the presence of saponins, anti-nutritional compounds contained in the pericarp of seed of some quinoa varieties (Gómez-Caravaca et al., 2011).

Saponins are a large group of glycosides soluble in water, where they form solutions foaming. Present in all fractions of the plant, saponins have insecticidal, antibiotic, fungicidal, and pharmacological properties (Carlson et al., 2012; Vega-Gálvez et al., 2010), thus contributing to the plant's defence against pests and pathogens. However, most saponins have an intensely bitter flavour that reduces the organoleptic characteristics and the palatability of any products 
with a their rich content. Moreover, all saponins are potentially toxic if ingested in large quantities, because of their haemolytic activity, and there is therefore a longstanding controversy about their functions in food.

Saponins are formed by sugar chains and a triterpenoid aglycone (sapogenin), each representing about 50\% of the total weight of the molecule (Galwey et al., 1990). Three main structures of sapogenins, oleanolic acid, hederagenin and phytolaccagenic acid, have been identified (Ridout et al., 1991). In quinoa, over 20 different saponins have been described (Mizui et al., 1988; Ridout et al., 1991). These saponins derive from seven aglycones identified so far in the different parts of quinoa (flowers, fruits, seed coats and seeds) that in combination with the various sugar chains (arabinose, glucose and galactose) form the over 20 saponins until now discovered (Kuljanabhagavad et al., 2008). Gas chromatography is the widely used method to quantify quinoa saponins (Ridout et al., 1991).

Saponins are traditionally removed from quinoa by washing (moist method) the grain before cooking it, although mechanical dehulling by abrasion (dry method) is also effective (Mujica and Jacobsen, 1999). However, the moist method increases costs (due to drying the product) and grains may begin to germinate during the process, because quinoa has a very high germinative power. The dry method is cheaper than washing, but has the disadvantage that it does not eliminate all the saponin and if the efficiency is increased, some nutrients are lost (Wright et al., 2002).

The amount of saponins present in the quinoa seeds depends on genoptype: it is higher in bitter-flavour varieties than in sweet, or low-saponins, varieties. For saponin content, considerable genetic variation is available and several sweet genotypes with low saponin content have been selected (Vela and Cabrera,1984). However, although some Ecuadorian and Bolivian quinoa cultivars have very low levels of grain saponin and do not require post-harvest processing, they are photoperiod sensitive, while those from Chilean origin, almost all from high-saponin lines, are early maturing and thus more suitable for European conditions (Johnson and Ward, 1993; Jacobsen et al., 1996).

The selection criteria of genotype depend by the environment, the grain destination and use, the market demand (Mc Elhinny et al., 2007). Nevertheless, high levels of saponin are considered a major impediment to the diffusion of the crop (Bhargava et al., 2006) because they can affect the absorption and digestibility of nutrients (Maughan et al., 2004). Consequently, the development of varieties with low or no saponin is one of the important breeding objectives for quinoa (Spehar and Rocha, 2010).

Saponin content depends on the developmental stage of the crop, being low during branching and high during flowering (Bhargava et al., 2006). Drought reduces by $45 \%$ the accumulation of sapogenins in quinoa seeds, based on one study of severe water deficit conducted in Southern Europe (Gomez-Caravaca et al., 2012), whereas salinity has the opposite effect (Soliz-Guerrero et al., 2002; Pulvento et al., 2012). More recently, however, a significant increase of saponins and other seed components has been reported in an arid location (irrigated) as opposed to a cold temperate climate (rainfed) site (Miranda et al., 2012; Miranda et al., 2013). Thus, the above data suggest that additional studies must be conducted to elucidate how the environmental and the genotypic effects influence the seed saponin levels (Zurita et al., 2014).

The aim of this preliminary study was to identify, among superior genotypes for seed production and quality traits, those with reduced grain saponin content to be used in subsequent genetic improvement programs for developing highly yielding varieties with improved nutritional qualities.

\section{Materials and methods}

\section{Plant materials}

In this paper we analyse the quantitative/qualitative assessment of saponins, determined in 8 quinoa accessions from different origin, previously selected for productivity and quality traits and one commercial variety (Regalona Baer), of Chilean origin, used as a control.

Selection, development and planting of materials used have been previously described (De Santis et al., 2011; 2014, 2016). Briefly, 25 germplasm lines of Chenopodium quinoa, 4 lines of $C$. giganteum, 1 line of $C$. berlandieri subsp. nuttalliae, from different geographical origins, were evaluated for seed yield and a range of morphological and quality traits, during the years 2009 and 2010 , at the Cereal Research Centre in Foggia (southern Italy: $41^{\circ} 28^{\prime} \mathrm{N}$; $15^{\circ} 34^{\prime} \mathrm{E}$; $76 \mathrm{~m}$ a.s.l.). The soil was characterised by a clay-loam texture, with the following characteristics: $21 \%$ clay, $43 \%$ silt, $36 \%$ sand, $\mathrm{pH} 8$ (in $\left.\mathrm{H}_{2} \mathrm{O}\right), 1.2 \mathrm{~g} \mathrm{~kg}^{-1}$ total $\mathrm{N}$ (Kjeldahl method), $15 \mathrm{mg} \mathrm{kg}^{-1}$ available P (Olsen method), $800 \mathrm{mg}$ $\mathrm{kg}^{-1}$ exchangeable $\mathrm{K}\left(\mathrm{NH}_{4} \mathrm{Ac}\right.$ ), and $21 \mathrm{~g} \mathrm{~kg}^{-1}$ organic matter (WalkeyBlack method). The climatic data recorded during both of these experimental years are shown in Figure 1.

Field trials were established in April in both years. The seeds were manually sown in polystyrene seed trays and seedlings were then transplanted to field plots, which consisted of 3 rows $1.0 \mathrm{~m}$ long and $50 \mathrm{~cm}$ apart, with 10 plants per row. The experimental design was a ran-

$$
\begin{aligned}
& \text { Sample } \\
& \downarrow \\
& \text { Soxhlet for } 8 \mathrm{~h} \text { with chloroform }
\end{aligned}
$$
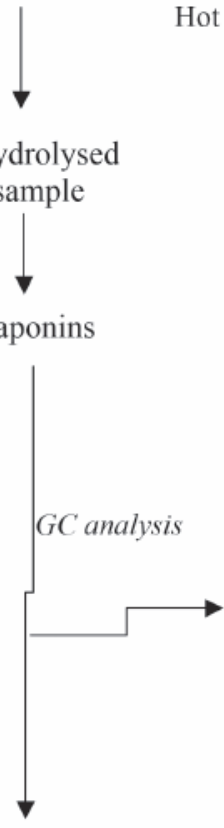

Figure 1. Analytical scheme for the extraction of saponins. TLC, thin layer chromatography; GC, gas chromatography. 
domised complete block with three replications. Chemical fertilisers were applied both before and during the experimental period: in autumn, with $200 \mathrm{~kg} \mathrm{ha}^{-1}$ of ammonium diphosphate $\left(36 \mathrm{~kg} \mathrm{ha}^{-1}\right.$ of $\mathrm{N}$, $92 \mathrm{~kg} \mathrm{ha}^{-1}$ of $\mathrm{P}_{2} \mathrm{O}_{5}$ ), during vegetative growth (in May), with $200 \mathrm{~kg} \mathrm{ha}^{-1}$ of ammonium nitrate ( $38 \mathrm{~kg} \mathrm{ha}^{-1}$ of $\left.\mathrm{N}\right)$. Irrigation was provided with three applications of $200 \mathrm{~m}^{3} \mathrm{ha}^{-1}$, each) and weed control was managed by hand removal when required. The quinoa lines and cv. Regalona Baer were harvested at maturity (20 $0^{\text {th }}$ August 2009 and $15^{\text {th }}$ July 2010).

\section{Parameters estimated}

Quinoa saponins were evaluated in terms of sapogenins (GomezCaravaca et al., 2012) (Figure 1). A gas chromatographic procedure was applied for the evaluation of saponin aglycones (sapogenins) derived from the acid hydrolysis of samples (Ridout et al., 1991).

Three major quinoa saponin aglycones were identified: oleanolic acid, hederagenin and phytolaccagenic acid, therefore values for the only these aglycones were reported.

\section{Data analysis}

For all the traits, statistical parameters of means, range, standard errors, variance and coefficients of variation were calculated over the two growing seasons for the whole collection by means of Graf Pad Instat 3 (Microsoft Software) statistics program.

Analyses of variance were computed separately for each year for all of the traits, and then combined over the years. The expected mean squares were based on a mixed linear model, with the genotypes having fixed effects and the years being random.

\section{Results and discussion}

The climatic characteristics of the trial site are typical of the Mediterranean climate, which is characterised by long dry summers and mild winters, with occasional frosts. Over the two years of the trial, the total rainfall was variable, particularly for its distribution during the growing season (Figure 2). The first year of the trial was wetter than the second year, with $341 \mathrm{~mm}$ of rain over the March to August period. Of this, $98.5 \mathrm{~mm}$ were concentrated in April and $65.2 \mathrm{~mm}$ in June, at the flowering stage. In contrast, the second year was relatively drier, with $201 \mathrm{~mm}$ of rain for the March-August period, with several not effective rainfall events during the growing season (Figure 2).

The differences between climatic conditions over these two seasons affected the saponin content of the evaluated quinoa accessions, resulting in a significant difference between the two seasons of research (1.10 and $0.92 \%$, for 2009 and 2010 , respectively).

The rainfall recorded in the first year, rainier than the second one, was concentrated in the last 10-day period of April (at the beginning of the growing season) and so it provided high level of air humidity and soil moisture. Moreover, the rainfall at June $(65.2 \mathrm{~mm})$ was concentrated in the second and third 10-day periods, when the crop was at early flowering stage, clearly affecting both flowering and seed-filling stages. The conditions wetter in the 2009 than in 2010 , were favourable also for main pests (fungi, bacteria, insects); for this reason the metabolism of the crop was oriented in a higher synthesis of saponins in the first than in the second year. No significant interaction year $\times$ genotype was observed.

These results are in agreement with the study of Soliz-Guerrero et al. (2002), who reported that saponin content is affected by a soil-water deficit, to the extent that high water deficits promote low saponin contents and with Pulvento et al. (2012) who obtained, for a quinoa genotype (Titicaca), the highest saponin values in samples with full irrigation treatments.
The contrasting results of Miranda et al. $(2012,2013)$ who reported in Chile an increase of saponin content in an arid, but irrigated environment and a decrease, in rainy environment not for all the genotypes, suggest, in agreement with Zurita et al. (2014), that additional studies must be conducted to elucidate how the environmental and the genotypic effects influence the seed saponin levels.

The total saponin content from all the aglycones (Aglycone I-VII) in whole seeds of quinoa accessions and R. Baer variety ranged from 0.05 to $2.00 \%$, indicating a large variability for this character (Table 1). The gas chromatographic analysis showed that all accessions, except the Q19 (1.80\%) had values below the control Regalona Baer, considered a medium-bitter variety. Five genotypes were potentially soft values below 1\%. The Q18, Q21, Q22 and Q29 accessions resulted equal, with an average of $0.57 \%$, unlike the $\mathrm{Q} 26$, resulted in absolute, the accession with the lowest saponin content $(0.01 \%)$.

From a qualitative point of view, confirmed also by the literature (Ridout et al., 1991), three major quinoa saponin aglycones were identified: oleanolic acid (Aglycone I) (36-50\% total), hederagenin (Aglycone II) (27-28\%) and phytolaccagenic acid (Aglycone III) (21$36 \%)$.

In Table 2 were reported the results for seed production and some quality traits in the eight selected accessions. They, almost all of Chilean origin, were found to be the most productive (with values of more than $2 \mathrm{t} \mathrm{ha}^{-1}$ seed) and with high levels of proteins (range 16.0$17.8 \%$ ) and fibres (9.4 and 14.6\%) (De Santis et al., 2014) among the 30 accessions previously evaluated.

Among the 5 accessions with low saponins content emerged in this
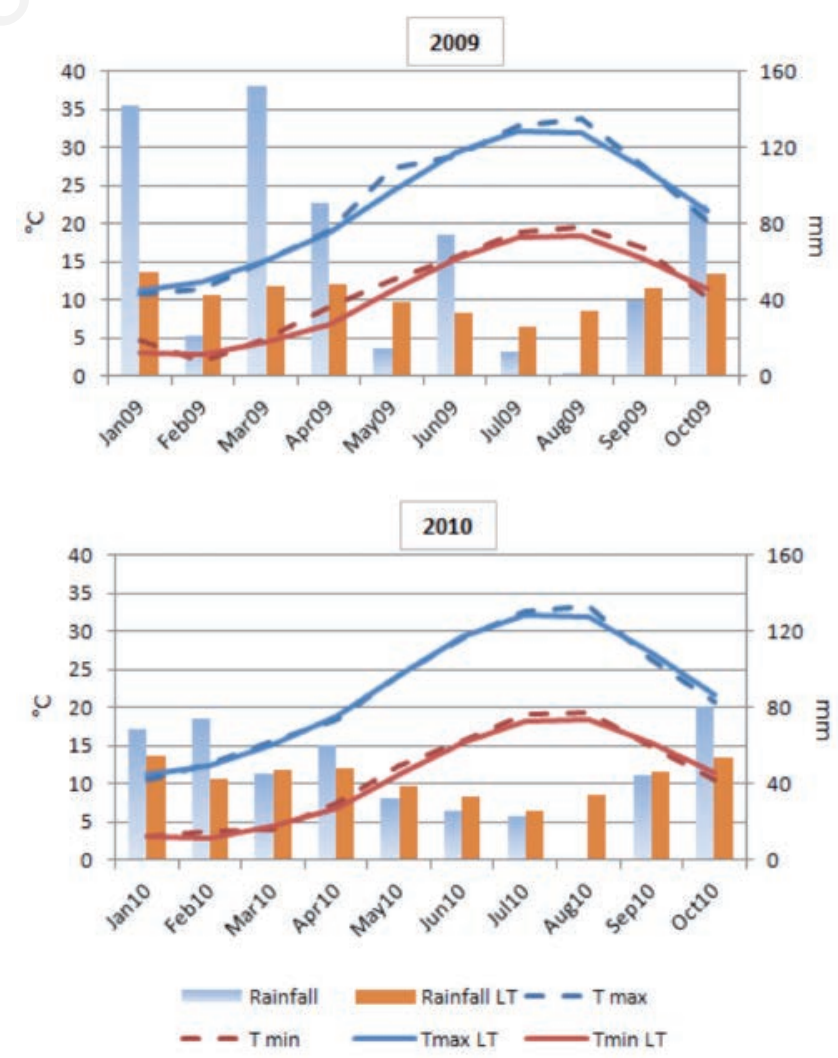

Figure 2. Monthly climatic data during the two trial years (2009 and 2010), compared to long-term average (1953-2008). 
Table 1. Means and significance for main sapogenins (Aglycone I-II-III) and total saponin content found in eight accessions and one variety (Regalona Baer) of quinoa (Chenopodium quinoa Willd.) in the two trial years (2009 and 2010).

\begin{tabular}{llcccc} 
Accession code & Origin & Aglycone I & Aglycone II & $\begin{array}{c}\text { Aglycone III } \\
\left(\text { mg kg }^{-1}\right)\end{array}$ & $\begin{array}{c}\text { Total saponins (I-VII) } \\
(\%)\end{array}$ \\
Q26 & Chile & $278^{\mathrm{i}}$ & $126^{\mathrm{f}}$ & $182^{\mathrm{g}}$ & $0.12^{\mathrm{f}}$ \\
Q29 & Chile & $828^{\mathrm{g}}$ & $87^{\mathrm{d}}$ & $761^{\mathrm{f}}$ & $0.54^{\mathrm{e}}$ \\
\hline Q21 & Bio-Bio (Chile) & $758^{\mathrm{h}}$ & $759^{\mathrm{e}}$ & $827^{\mathrm{e}}$ & $0.56^{\mathrm{e}}$ \\
Q18 & Maule (Chile) & $848 \mathrm{f}$ & $758^{\mathrm{e}}$ & $821^{\mathrm{e}}$ & $0.56^{\mathrm{e}}$ \\
\hline Q22 & Chile & $945^{\mathrm{e}}$ & $841^{\mathrm{d}}$ & $824^{\mathrm{e}}$ & $0.69^{\mathrm{d}}$ \\
Q27 & Chile & $1831^{\mathrm{d}}$ & $2597^{\mathrm{a}}$ & $2213^{\mathrm{d}}$ & $1.51^{\mathrm{c}}$ \\
\hline Q12 & Colorado (USA) & $2566^{\mathrm{c}}$ & $2546^{\mathrm{b}}$ & $2490^{\mathrm{c}}$ & $1.63^{\mathrm{b}}$ \\
Q19 & Bio-Bio (Chile) & $2709^{\mathrm{b}}$ & $2423^{\mathrm{c}}$ & $2632^{\mathrm{b}}$ & $1.76^{\mathrm{a}}$ \\
\hline R. Baer & Chile & $2903^{\mathrm{a}}$ & $2584^{\mathrm{a}}$ & $2761^{\mathrm{a}}$ & $1.77^{\mathrm{a}}$ \\
2009 & - & $1641^{\mathrm{a}}$ & $167^{\mathrm{a}}$ & $1479^{\mathrm{b}}$ & $1.10^{\mathrm{a}}$ \\
\hline 2010 & - & $1395^{\mathrm{b}}$ & $1366^{\mathrm{b}}$ & $1524^{\mathrm{a}}$ & $0.2^{\mathrm{b}}$ \\
\hline
\end{tabular}

${ }^{\text {a-i} D i f f e r e n t ~ l e t t e r s ~ i n d i c a t e ~ s i g n i f i c a n t ~ d i f f e r e n c e s ~ a m o n g ~ g e n o t y p e s ~ a n d ~ b e t w e e n ~ y e a r s ~(S t u d e n t-N e w m a n-K e u l s ~ t e s t, ~} \mathrm{P} \leq 0.05$ ).

Table 2. Means and standard error for seed yield and seed quality traits in eight accessions and one variety (Regalona Baer) of quinoa (Chenopodium quinoa Willd.) combined over the two years.

\begin{tabular}{|c|c|c|c|c|c|c|c|}
\hline Accession code & Origin & $\begin{array}{l}1000 \text { Seed weight } \\
\text { (g) }\end{array}$ & $\begin{array}{l}\text { Harvest } \\
\text { index }\end{array}$ & $\begin{array}{l}\text { Seed yield } \\
\left(\mathrm{th} \mathrm{a}^{-1}\right)\end{array}$ & $\begin{array}{l}\text { Seed protein } \\
(\%)\end{array}$ & $\begin{array}{l}\text { Seed total } \\
\text { dietary fibre } \\
(\%)\end{array}$ & $\begin{array}{l}\text { Seed total } \\
\text { saponins } \\
(\%)\end{array}$ \\
\hline Q19 & Bio-Bio (Chile) & 2.23 & 0.17 & 2.18 & 17.04 & 14.31 & 1.76 \\
\hline Q21 & Bio-Bio (Chile) & 2.58 & 0.24 & 2.30 & 16.39 & 9.35 & 0.56 \\
\hline Q12 & Colorado (USA) & 2.48 & 0.31 & 3.05 & 16.81 & 9.60 & 1.63 \\
\hline Q29 & Chile & 2.29 & 0.27 & 2.75 & 16.21 & 14.06 & 0.54 \\
\hline Q18 & Maule (Chile) & 2.60 & 0.25 & 3.01 & 16.65 & 11.85 & 0.56 \\
\hline Q26 & Chile & 2.30 & 0.17 & 2.15 & 15.98 & 9.51 & 0.12 \\
\hline Q22 & Chile & 1.94 & 0.17 & 2.01 & 17.77 & 14.14 & 0.69 \\
\hline Q27 & Chile & 2.46 & 0.18 & 2.87 & 15.96 & 14.65 & 1.51 \\
\hline \multirow[t]{2}{*}{ R. Baer } & Chile & 2.20 & 0.26 & 2.65 & 16.03 & 11.54 & 1.77 \\
\hline & Mean \pm SE & $2.34 \pm 0.07$ & $0.22 \pm 0.01$ & $2.55 \pm 1.24$ & $16.54 \pm 0.18$ & $11.90 \pm 0.35$ & $1.01 \pm 0.08$ \\
\hline
\end{tabular}

SE, standard error.

research, those that also presented a high seed productivity and a combined good value for qualitative characteristics, are as follows: Q18 and Q29, with a productivity of 3.01 and $2.75 \mathrm{tha}^{-1}$, respectively, and with a medium-high content of protein and fibres (16.5 and 13.0\%, on average, respectively).

\section{Conclusions}

In the present study, the data for this two-seasons trial confirm or support the low potential saponin content for some of the selected quinoa accessions, however, this was strongly determined by the specific climatic conditions: higher saponins content in the rainy year and lower in the drier one. The large differences between climatic conditions over the two seasons of the trial allowed the assessment of plant behaviour under drought stress (2010), as a comparison to optimal conditions (2009), and hence to identify lines with good adaptability in the environment trials. Data revealed a wide genetic variability for the saponins content, suggesting the possibility of selecting genotypes sweet to be used in subsequent genetic improvement programs. Based on the results, in fact, it was possible to identify, among accessions pre- viously selected, particularly suitable for growing in Mediterranean area, some genotypes with high yields of seed $\left(2.5 \mathrm{t} \mathrm{ha}^{-1}\right.$, on average), high protein (17\%, on average) and fibres (13\%, on average) and with a very low content in saponins $(0.57 \%$, on average).

\section{References}

Bertero D.H., 2001. Effects of photoperiod, temperature and radiation on the rate of leaf appearance in quinoa (Chenopodium quinoa Willd.) under field conditions. Ann. Botany 87:495-502.

Bhargava A., Shukla S., Ohri D., 2006. Chenopodium quinoa. An Indian perspective. Ind Crops Prod 23:73-87.

Carlson D., Fernandez J.A., Poulsen H.D., Nielsen B., Jacobsen S.E., 2012. Effects of quinoa hull meal on piglet performance and intestinal epithelial physiology. J. Animal Physiol. Animal Nutr. 96:198205.

Casini P., 2002. Possibilità di introdurre la Quinoa in ambienti mediterranei. Inf. Agr. 27:29-32 [In Italian].

Chillo S., Civica V., Iannetti M., Suriano, N., Mastromatteo M., Del Nobile MA., 2009. Properties of quinoa and oat spaghetti loaded 
with carboxymethyl cellulose sodium salt and pregelatinized starch as structuring agents. Carbohydrate Polymers 78:932-7.

De Santis G., D’Ambrosio T., Rascio A., De Vita P., 2011. Caratterizzazione morfologica e qualitativa di genotipi di quinoa (Chenopodium quinoa Willd.) in ambiente Mediterraneo. pp 173177 in Proc. $8^{\circ}$ Convegno AISTEC Evoluzione e rilancio della filiera dei cereali, Catania, Italy.

De Santis G., D’Ambrosio T., Rinaldi M., Rascio A., 2016. Heritabilities of morphological and quality traits and interrelationships with yield in quinoa (Chenopodium quinoa Willd.) genotypes in the Mediterranean environment. J. Cereal Sci. 70:177-85.

De Santis G., Rascio A., D’Ambrosio T., D’Angelo L., Fragasso M., Maddaluno C., Mucci M., Rinaldi M. 2014. Valutazione della biodiversità in popolazioni di quinoa (Chenopodium quinoa Willd.) in ambiente Mediterraneo. pp 426-433 in Proc. X Convegno Nazionale sulla Biodiversità, 3-5 settembre 2014, Roma, Italy.

Galwey N.W., Leakey C.L.A., Price K.R., Fenwick G.R., 1990. Chemical composition and nutritional characteristics of quinoa (Chenopodium quinoa Wild.). Food Sci. Nutr. 42F:241-61.

Gambus H., Gambus F., Sabat F., 2002. The research on the quality improvement of gluten free bread by amaranthus flour addition. Zywnosc 9:99-112.

Gómez-Caravaca A.M., Segura-Carretero A., Fernández-Gutiérrez A., Caboni A.F., 2011. Simultaneous determination of phenolic compounds and saponins in quinoa (Chenopodium quinoa Willd.) by a liquid chromatography-diode array detection-electrospray-ionization-time-of-flight mass spectrometry methodology. J. Agric. Food Chem. 59:10815-25.

Jacobsen S.E., 1997. Adaptation of quinoa (Chenopodium quinoa) to Northern European agriculture: studies on developmental pattern. Euphytica 96:41-8.

Jacobsen S.E., 2003. The worldwide potential of quinoa (Chenopodium quinoa Willd.). Food Rev. Int. 19:167-77.

Jacobsen S.E., Hill J., Stolen 0., 1996. Stability of quantitative traits in quinoa (Chenopodium quinoa). Theor. Appl. Genet. 93:110-226.

Johnson D.L., Ward S., 1993. Quinoa. In: J. Janick, J.E. Simon (Eds.), New crops. Wiley, New York, NY, USA, pp 222-227.

Koziol M.J., 1992. Chemical composition and nutritional value of quinoa (Chenopodium quinoa Willd.). J. Food Comp. Anal. 5:35-68.

Kuljanabhagavad T., Thongpasuk P., Chamulitrat W., Wink M. 2008. Triterpene saponins from Chenopodium quinoa Willd. Phytochemistry, 69:1919-26.

Maughan P.J., Bonifacio A., Jellen E.N., Stevens M.R., Coleman C.E., Ricks M., Mason S.L., Jarvis D.E., Gardunia B.W., Fairbanks D.J., 2004. A genetic linkage map of quinoa (Chenopodium quinoa) based on AFLP, RAPD, and SSR markers. Theor. Appl. Genet. 109:1188-95.

Mc Elhinny E., Peralta E., Mazón N., Danial D.L., Thiele G., Lindhout P., 2007. Aspects of participatory plant breeding for quinoa in marginal areas of Ecuador. Euphytica 153:373-84.
Miranda M., Vega-Gálvez A., Quispe-Fuentes I., Rodriguez M.J., Maureira H., Martinez E.A., 2012. Nutritional aspects of six quinoa (Chenopodium quinoa Willd.) ecotypes from three geographical areas of Chile. Chilean J. Agric. Res. 72:175-81.

Miranda M., Vega-Gálvez A., Martínez E.A., López J., Marín R., Aranda M., Fuentes F., 2013. Influence of contrasting environments on seed composition of two quinoa genotypes: nutritional and functional properties. Chilean J. Agric. Res. 73:108-16.

Mizui F., Kasai R., Ohtani K., Tanaka 0., 1988. Saponins from brans of quinoa, Chenopodium quinoa Willd. Chem. Pharm. Bull. 36:1415-8.

Mujica A., Jacobsen S.-E., 1999. Tecnologia de postcosecha de granos andinos: Quinua (Chenopodium quinoa Willd.). pp 5-8 in Proc. I Curso taller sobre Produccion comercializacion y Uso de la Quinoa para Agricultura de la Zona de Iquique, Chile. CONADI, Puno, Peru.

Pulvento C., Riccardi M., Lavini A., Iafelice G., Marconi E., d'Andria R., 2012. Yield and quality characteristics of quinoa grown in open field under different saline and non-saline irrigation regimes. J. Agron. Crop Sci. 198:254-63.

Ridout C.L., Price K.R., Du Pont M.S., Parker M.L., Fenwick G.R., 1991. Quinoa saponins-analysis and preliminary investigations into the effects of reduction by processing. J. Sci Food Agric. 54:165-76.

Risi C.J., Galwey N.W., 1984. The Chenopodium grains of the Andes: Inca crops for modern agriculture. In: T.H. Coaker (Ed.), Advances in applied biology, Vol. X. Academic Press, Inc., London, UK, pp 145216.

Soliz-Guerrero J.B., de Rodriguez D.J., Rodríguez-García R., AnguloSánchez J.L., Méndez-Padilla G., 2002. Quinoa saponins: concentration and composition analysis. In: J. Janick and A. Whipkey (Eds.), Trends in new crops and new uses. ASHS Press, Alexandria, VA, USA, pp 110-114.

Spehar C.R., Silva Rocha J.E., 2010. Exploiting genotypic variability from low-altitude Brazilian Savannah-adapted Chenopodium quinoa. Euphytica 175:13-21.

Tosi E.A., Ciappini M.C., Masciarelli R., 1996. Utilisation of whole amaranthus (Amaranthus cruentus) flour in the manufacture of biscuits for coeliacs. Alimentaria 34:49-51.

Vega-Gálvez A., Miranda M., Vergara J., Uribe E., Puente L., Martínez E.A., 2010. Nutrition facts and functional potential of quinoa (Chenopodium quinoa Willd.), an ancient Andean grain: a review. J. Sci. Food Agric. 90:2541-7.

Vela N.P., Cabrera L.J.A., 1984. Utilizacion de la semilla de quinua en la alimentacion humana. Technologia 25:7-27 [in Portughese].

Wright K.H., Pike 0.A., Fairbanks D.J., Huber C.S.,2002. Composition of Atriplex hortensis, sweet and bitter Chenopodium quinoa seeds. J. Food Sci. 67:1383-5.

Zurita-Silva A., Fuentes F., Zamora P., Jacobsen S-E., Schwember A.R., 2014. Breeding quinoa (Chenopodium quinoa Willd.): potential and perspectives. Mol. Breed. 34:13-30. 